\title{
EHMTI-0189. Tryptophan-kynurenine metabolism in migraine patients
}

\author{
Z Majláth $^{1 *}$, G Veres ${ }^{1}$, D Zádori ${ }^{1}$, A Balog ${ }^{2}$, N Watti ${ }^{2}$, J Tajti ${ }^{1}$, L Vécsei $^{3}$ \\ From 4th European Headache and Migraine Trust International Congress: EHMTIC 2014 \\ Copenhagen, Denmark. 18-21 September 2014
}

\section{Introduction}

Alterations of the serotoninergic system are well-known in migraine, however, the other main route of tryptophan metabolism, the kynurenine pathway has not yet been investigated in migraine. Psychiatric comorbidity, especially depression is highly frequent in migraine patients, but the exact pathomechanism is not fully clarified.

\section{Aims}

To investigate kynurenine metabolites in migraine patients, and to assess psychiatric comorbidity.

\section{Methods}

The study was approved by the Ethical Committee of the University of Szeged. 47 migraine patients and 43 healthy controls have been involved, written informed consent was obtained from every participant. Headache patients were classified according the IHS criteria. Depression, anxiety, stress, and quality of life were assessed by validated questionnaires: the Beck Depression Inventory, the Holmes and Rahe Stress Scale, the SF-36, and the Spielberger State-Trait Anxiety Inventory. Serum samples have been analyzed by HPLC.

\section{Results}

$31 \%$ of migraine patients presented depressive symptoms. Migraine patients had a significantly lower quality of life, which showed a strong correlation with psychiatric comorbidity. Tryptophan levels were significantly lower in migraineurs than in controls. Serum indoleamine 2,3-dioxygenase (IDO) activity, calculated by kynurenine/tryptophan ratio, was significantly higher in migraine patients with depressive symptoms, while in

${ }^{1}$ Department of Neurology, University of Szeged, Szeged, Hungary

Full list of author information is available at the end of the article non-depressed patients IDO activity was not statistically different.

\section{Conclusions}

Psychiatric comorbidity, especially depression is highly prevalent among migraine patients, and contributes to the worsening of quality of life. The alterations in tryptophan-kynurenine metabolism might contribute to pathomechanism of migraine and depression comorbidity.

No conflict of interest.

\section{Authors' details}

${ }^{1}$ Department of Neurology, University of Szeged, Szeged, Hungary. ${ }^{2}$ Faculty of Medicine, University of Szeged, Szeged, Hungary. ${ }^{3}$ Neuroscience Research Group of the Hungarian Academy of Sciences (MTA - SZTE Neuroscience Research Group), University of Szeged, Szeged, Hungary.

Published: 18 September 2014

doi:10.1186/1129-2377-15-S1-E17

Cite this article as: Majláth et al.: EHMTI-0189. Tryptophan-kynurenine metabolism in migraine patients. The Journal of Headache and Pain 2014 15(Suppl 1):E17.

\section{SpringerOpen ${ }^{\circ}$}

(C) 2014 Majláth et al; licensee Springer. This is an Open Access article distributed under the terms of the Creative Commons Attribution License (http://creativecommons.org/licenses/by/2.0), which permits unrestricted use, distribution, and reproduction in any medium, provided the original work is properly cited.
Submit your manuscript to a SpringerOpen ${ }^{\circ}$ journal and benefit from:

- Convenient online submission

- Rigorous peer review

- Immediate publication on acceptance

- Open access: articles freely available online

- High visibility within the field

- Retaining the copyright to your article

Submit your next manuscript at springeropen.com 